Bulletin de

$L \cdot A \cdot P \cdot A \cdot D$

\section{Bulletin de l'APAD}

12| 1996

Le développement négocié : courtiers, savoirs, technologies (II)

\title{
Beyond 'Negotiation' Challenges of Participatory Projects for the Anthropology of Development
}

Jeremy Gould

\section{(2) OpenEdition \\ Journals}

Édition électronique

URL : http://journals.openedition.org/apad/603

DOI : 10.4000/apad.603

ISSN : 1950-6929

Éditeur

LIT Verlag

Édition imprimée

Date de publication : 1 décembre 1996

Référence électronique

Jeremy Gould, « Beyond 'Negotiation' Challenges of Participatory Projects for the Anthropology of Development », Bulletin de l'APAD [En ligne], 12 | 1996, mis en ligne le 24 avril 2007, consulté le 10 décembre 2020. URL : http://journals.openedition.org/apad/603; DOI : https://doi.org/10.4000/apad 603

Ce document a été généré automatiquement le 10 décembre 2020.

Bulletin de I'APAD 


\title{
Beyond 'Negotiation' Challenges of Participatory Projects for the Anthropology of Development
}

\author{
Jeremy Gould
}

1 The notion of 'negotiated development' implies the 'unpacking' of a predetermined technological package by local brokers in accordance with their own needs and interests. Studies elaborating this proposition have given rise to a stimulating literature which generally defends the thesis that development interventions must be studied as only one element of a broader process of social change ${ }^{1}$.

2 I have been much inspired by the methodological foundations of this perspective, at the roots of which is an 'actor-oriented' approach to the study of social change. Especially fruitful is the reaffirmation in this approach of the social constructivist emphasis on incorporating the perspectives of different groups of actors in an interactionist framework. This perspective is essential if we are to uncover 'the very processes that produce and reproduce particular structural forms' that enable and constrain social action $^{2}$. As David Booth suggests, these methodological guidelines, applied creatively to empirical study, can generate profound insights into how 'development interventions' become embedded in and activate specific social, cultural, economic and political matrices. But, the usefulness of the 'actor-oriented perspective' may be diminished if it is tied -as the 'negotiated development thesis suggests- to a specific, pre-empirical conceptualization of how the social relations of a 'development intervention' are constituted.

In this paper, I question the relevance of some of the assumptions underlying the 'negotiated development' thesis for the analysis of an important class of contemporary development interventions. What I have in mind are the 'new generation ' of projects designed around 'participatory' methodologies. I will argue that these methodologies are rapidly becoming the mainstream in the practice of 'rural development' and that this fact forces us to rethink a number of critical issues about the 'anthropology of social change and development' . 
The assumptions I will contest concern the conceptualization of the generic 'development project' as an essentially 'expert-stance, supply-driven, top-down, modernization-oriented' endeavor which revolves around the delivery of a predetermined technological package. Intrinsic to this model is a view that the 'lines of negotiation' are the same institutional boundaries that separate the state from civil society. According to this image, the interests of the targeted beneficiaries of a technology (e.g., small scale rural producers) depart automatically from those of the local level deliverers of the technological package (e.g., agricultural extension workers).

This view reflects the situation that prevailed in the rural development industry from the colonial era up until the late 1980s. This is the period which produced the formative studies underlying the 'negotiated development' thesis. Undoubtedly, the unilateral, topdown approach still has leverage in certain contexts. My impression, however, is that it is increasingly on the wane. I argue that an important category of 1990s rural development projects has learned from past errors (and critiques), and that their design principles have undergone something of a metamorphosis. If this is true, I think it has important consequences for how we think about rural development and, equally important, for how anthropologists engage in development interventions.

These observations derive primarily from an analysis of three extension-based projects : a livestock development project in Western Kenya, a community-based small dam construction program in a drought-affected region of Zimbabwe, and a food security project in northeastern Zambia ${ }^{3}$. The general principles underlying ail three projects were virtually identical. Most important for the thesis I am outlining here was my study of the Zambian project, the Luapula Livelihood and Food Security Program, an intervention which is taking place in an area I studied intensively for several years in the mid-eighties.

7 My central observation is that the 'new generation' of participatory projects is contributing to a major transition in the relationship between rural communities and local administrative structures in many parts of Africa. My focus is on agriculture, especially the extension service, but similar developments would appear to be underway in health, water and community development. This can be seen as part of a more general process of the 'pluralization' of approaches to development interventions. As Ian Christoplos and Urich Nitsch have recently noted, '[G]randiose planning [of extension systems] is giving way to an effort to understand and influence (rather than design and control) social processes' ${ }^{4}$. To substantiate this for my particular cases, let me provide a brief overview of the history of development interventions in Luapula.

Luapula : a century of 'development'

8 The Central African region of northeastern Zambia we know today as Luapula was settled in waves of eastward immigration from present day Angola over the past four to five hundred years. By the late 18th century, the Luapula river valley constituted the fulcrum in a chain of long-distance trading networks expanding from the Atlantic to the Indian Oceans. Waves of immigration from the Lunda-Luba empire of the Mwata Yamvo spawned a diffuse pattern of clan-based settlements along the high plateau on both sides of the Luapula river and in the rich river valley as well.

Well into this century. the peoples living in the Luapula region, especially those on the heavily forested plateau, practiced a complex and mobile economic system. Their repertoire of livelihoods has comprised hunting, fishing as well as slash-and-burn (citemene) cultivation of the miombo woodland. For the largest part of the population, 
fishing in numerous rivers and the two large lakes with their associated swamp/ floodplain systems has been the traditional mainstay, and fish has been the region's principle commercial commodity. Market-oriented agriculture has been marginal to the local economies, with the main emphasis being on the production of cassava, millet, groundnuts and beans for subsistence and local exchange. For the plateau populations living away from the artisanal fisheries, migratory labor to the mining towns of the Zambian and Zaïrean copperbelts has been the major source of cash ${ }^{5}$. With population growth the ecological conditions for citemene as a way of life dwindled ${ }^{6}$. This process was underway in parts of the region in the first decades of the colonial period (beginning 1924), yet hardly out of control. As discussed in detail by Megan Vaughan and Henrietta Moore, the extension service of the colonial administration was obsessed with environmental degradation and focused virtually ail its efforts up until the second World War on rooting out the practice of citemene?

10 The post-war period marked a new era of 'late colonialism' in Zambia. Growing nationalist and anti-colonial sentiments among the African populations posed a threat to colonial stability. At the same time, an ideology of 'development' (emanating from Bretton Woods) expressed new notions of how to appease restless populations. The 1950s saw a series of regional development initiatives in the Luapula area. The first, based on an ambitious 'Luapula-Bangweulu Area Plan', encompassed numerous small to medium-sized projects between 1951 and 1955 which were geared to direct intervention in local agriculture ${ }^{8}$.

11 Colonial conceptions of indigenous production systems were generally denigratory ${ }^{9}$. According to the prevailing wisdom of colonial administrators, peasant producers were guilty of the gross mismanagement of land, water and associated flora and fauna. Hence, colonial rural development implied a complete renovation of both small-holder production techniques and land-use patterns. Innovations aimed at promoting cash crops and improving productivity, but there was a strong emphasis on conservation measures as well. Kusum Datta notes of the prevailing agricultural policy : '[W]orking on the premise that the African cultivator was his own enemy, imperial conservationists introduced complex schemes with little relevance to the actual conditions in the colony' ${ }^{10}$. Under the influence of the Luapula-Bangweulu Area Team, numerous new regulations were introduced and enforced to enhance rural conditions. These included the banning of fishing nets of small mesh, even outside the commercial fisheries and among subsistence fishermen; forbidding the traditional practice of late bush burning; imperatives requiring households to expand the number of gardens cultivated; the imposition of stringent weeding regulations; forbidding mixed farming ; and the mandatory ridging of fields ${ }^{11}$.

12 To save money, the post-war colonial agricultural projects were designed to involve a small number of individuals in selected areas in the hope that success would trickle down into the economic environment via the 'demonstration effect' ${ }^{12}$. Successful dissemination of new chemo-genetic technologies (focusing on maize and groundnuts) was hampered by the rigidity of the technical staff. Development was understood as the obedient replication of the demonstrated techniques, and agricultural officers responded with neglect or disciplinary measures to innovative villagers who did not conform to preconceived notions of 'improved management'.

Colonial extension : the Peasant Farming Scheme 
13 At the core of the colonial rural development effort was the Peasant Farming Scheme. This program was originally designed for the second generation cash-crop production areas of the Eastern and Central Provinces which were ecologically and socially very different from conditions found in Luapula. The PFS came to the northeastern region of Zambia in $1951^{13}$. According to the guidelines of the scheme, potential peasant farmer volunteers were to occupy blocks of land provided through 'a form of leasehold tenancy' by the Native Authority, a kind of proto-cooperative under state tutelage.. Land was cleared by the Government, if so desired, and draught animals provided to the volunteers. These services were financed through a loan to the volunteer to be repaid in kind. In 1951, seven volunteers began at Ndoba Road near Lake Bangweulu. The next year another nine volunteers commenced Peasant Farming in Mushota, on the Kawambwa plateau. By 1954, farmers had dwindled to 12 , six on both sites. At the same time, the Director of Agriculture noted that 593 individual settlements had sprung up spontaneously across the northeastern region and that farmers were requesting support services similar to those provided to PFS volunteers. 'This development', remarked the Director, 'has raised important questions on land tenure which are exercising the minds of ail concerned with policy and administration of the PFS' ${ }^{14}$.

By the next year, 1955, nine hundred individual peasant farmers were mapped and under observation in the northeastern region (compared to less than 100 Peasant Farmers, of whom twenty were in present-day Luapula). Nonetheless, no action was taken in support of these innovators, since their 'agricultural methods leave much to be desired' and the 'land tenure implications' were still unresolved. It seems obvious that hundreds if not thousands of households were eager to penetrate the agricultural market but were suspicious of the ambiguous, Government-controlled land-tenure arrangement. Hence, the colonial administration missed a choice opportunity to achieve its objective of expanding production for the agricultural market on an exponentially increasing scale. The obstacle in this case was the agricultural officers 'fixation on an abstract notion of 'improved management' and on formalized land tenure agreements. Colonial development thinking was unable to overcome the belief that traditional usufructuary land rights were too primitive as a basis for modem agriculture.

In 1957, the Director of Agriculture was willing to concede that support to individual farmers 'may well prove to be more satisfactory under the extensive conditions obtaining', ${ }^{15}$ and loans were made available to individuals on a limited basis. However, there was still reluctance on the part of the administration to expand the scheme since experience had shown that peasant producers in the more remote areas are 'frequently reluctant to accept advice and to follow up-to-date farming methods' ${ }^{16}$. Hence, by 1962 when political unrest paralyzed colonial development projects only 318 farmers were involved in the scheme in the entire northeastern region.

One could thus summarize the character of extension in the colonial era as an obsession with control. There was little or no responsiveness to the dynamics of the local economy or its production systems. Of prime importance to the colonial administration was the use of the extension service as a tool of discipline and order. The zeitgeist of colonial extension was expressed concisely by the registrar of Cooperative Societies in 1947 when he proclaimed that, 'the African' must accept agricultural control, as and when the Agricultural Department considers it should be imposed and to whatever extent it considers desirable ${ }^{17}$. 
Post-independence extension - the case of the lima program

Independence from colonialism in 1964 changed the basic configuration of political power in Zambia. The broad program of social reforms launched by the United National Independence Party government of President Kenneth Kaunda, and the subsequent nationalization of the copper industry effected sweeping changes in both the ideology and practice of 'development'. Yet some important continuities in official thinking about rural society survived the transition from the colonial to the post-colonial state.

Echoing the rhetoric (if not the practices) of the colonial regime they inherited, the post-independent Zambian_government pursued a policy of chemo-genetic modernization as the solution to perceived problems of poverty and inequity. As was the case elsewhere, post-Independence campaigns to modernize the rural economy employed a top-to-bottom, transfer of technology model of development according to which solutions to the problems of the rural population can be imported from the 'modem' sector in the form of pre-existing agronomic, mechanical or organizational technologies. These interventions, which exemplify the 'technological package' image of development projects central to the 'negotiated development' perspective, dominated administrative practices throughout the 1st and 2nd Republics of UNIP rule, until the 1990s.

The technological package at the core of the post-Independence extension system was the promotion of hybrid maize. In many areas of Southern, Central and Eastern Zambia, maize production established itself as a viable cash- and food crop already in the 1930s ${ }^{18}$. In Luapula, maize production remained negligible until the 1980s when an aggressive maize promotion campaign, termed the Lima Program was launched under donor support and supervision ${ }^{19}$. Support for the Luapula lima program was based on an series of agreements between the Finnish and Zambian governments beginning in 1980 . In the background were the initiatives of a large Finnish agro-industrial company keen on breaking into the African fertilizer market. For the first few years of the project, agricultural inputs (seeds, fertilizers, pesticides) were supplied free of charge to first-year 'lima farmers'. Expatriate staff personally managed their gate-to-gate distribution as well as the collection of the marketable produce. In subsequent seasons farmers financed their inputs through a heavily subsidized, state/donor-managed credit facility (e.g., the 'Cooperative Credit Scheme'). A training module was also included in the project design, and prospective 'lima farmers' from target villages were selected by the local extension officer for training in 'modem agricultural techniques.'

Although the planning was justified by reference to Zambian policies and priorities, the project was designed, run and funded by expatriates. Several characteristics stand out. Training, credit and extension support were provided exclusively for production with 'improved varieties' of seed only available through parastatal channels. Farmers were reprimanded and even sanctioned (with the discontinuation of credit) for failure to comply with lima techniques (e.g., 'incorrect' fertilizer application). Intercropping and other 'traditional' practices were portrayed in the training program as inefficient. Advice was generally unavailable to trainees concerning the crops, techniques and situations upon which their livelihoods had hitherto depended - most notably the production of cassava, millet and staple legumes. In this respect, the Lima Pro gram reflected the established practices of the governmental extension service. Training was carried out in Farmer Training Centers at long physical distances from the trainees' place of residence. For the first six years of the project, trainees were almost 
exclusively men despite the fact that women have a much greater role in agriculture and in food production in particular .

The Zambian extension worker

21 In 1984, Swedish anthropologist Hans Hedlund published a seminal analysis of the Zambian extension worker based on his work in northwestern Province during the late $1970{ }^{20}$. His portrayal of 'the local extension worker, his attitudes and cognitive systems, and his relationship to the local community and the administration' graphically captures the contradictions embodied in the rural development policies of the day. Hedlund saw the Zambian extension worker as living outside the rural community in which he worked, encapsulated in a socially self-sufficient community of other government workers and their families. These educated professionals shared a set of values oriented toward urban life and lifestyles. Still, civil servants stationed in local communities represented the bottom rung of an extremely hierarchical bureaucracy. Monthly, the extension officer reported upward to the District Agricultural officer, and yet received no feedback or support from his superiors. The crux of his job was walking long distances to visit the farms of his client farmers and advise them on hybrid maize production. The extensionist typically managed to see each of his farmers about once a year. The extension package he sought to diffuse focused exclusively on hybrid maize and he was adamant about farmers' strict adherence to his advice. Nevertheless, in private Hedlund's extensionist expressed doubts as to whether the soils in his area were actually conducive for maize production.

In terms of resources and prestige the Ministry of Agriculture was one of the lowest-status ministries, and the Camp officer was its most menial professional position. The camp level extensionist was caught between the expectations of the local community and his superiors in the Ministry, yet enjoyed virtually no authority to mobilize any of the resources which would have made his educational task more effective. This was indicative of the situation at ail lower levels of the Ministry. Ali projects were designed in the capital of Lusaka. These projects had little chance of success since the rural areas in Northwestern Province and Luapula generally lacked the markets and basic infrastructure which would have been a precondition for commercial farming.

Thus shouldered with this relatively thankless task, the extensionist tended to have a negative view of both the community in which he worked and of the Department he represented. Hedlund portrays the situation of his example camp officer (whom he refers to as Ndumba) thus :

Ndumba found himself isolated both from his department, the local elite as well as from the villagers. Instead of generating economic change, he was mainly busy with passive observation - a situation he found static and uncomfortable. Ndumba was a messenger and himself a message of the government's lack of interest in the production and welfare of the communities ${ }^{21}$.

Philip Gatter, writing about fieldwork in Luapula in the late 1980s, reaffirms Hedlund's analysis, and attempts to give it a more theoretieal gloss. Gatter sees in the extension worker's dilemma a conflict between two discursive, or ideological formations. The extension worker is embedded in and oriented toward a 'productionist' ideology, while the villager assesses the extension worker, and the potential resources he can offer, within a 'distributionist' framework ${ }^{22}$. In other words, the extension worker is only concerned with getting the farmer to produce increasing volumes of maize, while the 
farmer unpacks the lima package into the elements (inputs, credit, etc.) which can be exploited to promote his or her position in a network of reciprocal relations. Unlike Hedlund's case of the disillusioned camp officer in Northwestern, Gatter's extensionists were relatively optimistic about the outcome of their work. The main difference, perhaps, is that while Hedlund was observing the downward spiral of a ill-conceived settlement scheme, Gatter, 10 years later, was riding the crest of a heavily subsidized 'maize boom' in Luapula.

Reassessments

Throughout the eighties, the Zambian government and the donor agency invested heavily in the lima program. Zambian government support came through its continued policy of producer and consumer subsidies, and through a low-interest credit scheme to maize producers via marketing cooperatives ; Finland and other donors gave support to transport, marketing, training and credit. In response to these incentives, Luapulans began to produce maize in volume. Marketed output increased nearly ten-fold over the course of the 1980s. Then, just as the program seemed poised to reap the rare fruits of 'development', the money ran out. First, the heavily indebted Zambian government was forced by its international creditors to remove agricultural subsidies. Soon after, the funding base of the donor agency responsible for the program was undercut by its own domestic recession. With the removal of artificial incentives and massive donor support, the economic basis for a State-centered, supply-driven rural development policy disappeared. Marketed maize output collapsed. In terms of the official blueprint for agricultural modernization, Luapula was back at square one. One consequence of this is that policy makers and aid-managers have been forced to reconsider their approaches.

One early veteran of the Finnida Lima Project's training staffhas subsequently had second thoughts about the ideological content of the program :

Unfortunately, the Finnish team may have conveyed to the students the impression that citemene was inherently primitive and condemnable [sic] while the use of chemo-genetic techniques is modem and to be striven after. The word modem undoubtedly has a strong brainwashing affect on audiences. It was brought out time and time again to imply something creditable rather than merely fashionable ${ }^{23}$.

This reassessment is symptomatic of widespread changes in thought about agricultural modernization in recent years. Since the late seventies, similar doubts had been germinating in the research branch of the Ministry of Agriculture. One outcome of these dissenting voices was the establishment of a network of Adaptive Research Planning Teams in most of the Provinces of Zambia during the 1980s.. The provincial ARPTs were established from 1980 onward 'to involve farmers, especially small farmers, more fully in the technology generation process' ${ }^{24}$. Over the years the ARPT approach (or approaches since the various Provincial teams develop their own distinctive characters) evolved vigorously toward a participatory style of research which sought to establish a 'farmer-researcher dialogue' as a basis for the research agenda.

Michael Drinkwater, an rural sociologist active in the ARPT working in the Central and Copperbelt Provinces reports on the attempts of ARPT scientists to forge a common language for agricultural practices with local farmers. Drinkwater's analysis is particularly interesting since he attempts to explicate the epistemological differences between the participatory methods central to the ARPT approach, and the positivist conception of knowledge in which a technology package model is based ${ }^{25}$. In 
Drinkwater's account, the crucial feature of participatory methods are their dialogic character. Scientists and farmers experience and conceptualize their lives and knowledge via rather distinct lifeworlds. Knowledge is not easily portable from one context to another - from the field of the Zambian villager to the research station of the western agronomist - because 'knowledge about agricultural practices is embedded in the performance of those practices and in the linking of these practices into an overall farming and livelihood system ${ }^{26}$. This is why it is so difficult to marry the bottom-up to the top-down approach to technological improvement. The task of bringing together the knowledge and the skills of the rural farmer and the researcher/extensionist requires 'an ongoing process where methods are linked over time as part of a continuing dialogue ${ }^{27}$.

The key lies in working out operational modes of communication between the scientist and the farmer; the bureaucrat and the rural citizen. Drinkwater's perspective challenges the assumption in much of the 'participation' literature that the central problem of 'development' is one of how to get peasants to 'participate' in the planning and implementation of development projects overseen by state agents and their donor allies. One lesson of the ARPT experiment has been that the problem of participation in development is not one of razing the barriers to citizen involvement in activities designed by people with little understanding of local conditions. What is needed is genuine collaboration between the agents that control external resources and local actors with first-hand experience of local problems in the search for viable solutions.

31 In some important respects, the ARPT pro gram has been a failure. It has often failed to get the results of its agronomic research accepted as the 'official' recommendation by the Ministry of Agriculture ${ }^{28}$. Nor has it managed to fully institutionalize its methodologies within the mainstream of agricultural research in Zambia. Nonetheless, the impact of these methodologies on rural development thinking in Zambia has been substantial and one can see the elements of participatory, dialogic approaches emerging in most of the new generation of interventions ${ }^{29}$.

The evolution of the ARPT program toward genuinely collaborative research methodologies was thus an important gestation period for the new generation of participatory projects which are now beginning to emerge. The Luapula case provides an unusually clear example of how various experiments and experiences have converged in the new-generation of participatory rural development projects. Already in the final days of the Finnida -supported lima pro gram (before its financial demise in 1992) local managers had begun to cautiously build up links with the Luapula ARPT and to pursue alternative agronomic models with a focus on on-farm activities. When the Finnish money ran out, the program had reached a conceptual crossroads of sorts. Methodologically, the project had outgrown the Lima concept, while at the same time liberalization of the grain market and the removal of agricultural subsidies rendered maize production commercially marginal in most of the Province. This was the point of departure when Finnida launched an 18-month participatory planning exercise in 1993 with the objective of formulating a new-style 'participatory' rural development program in Luapula.

The participatory approach

33 The launching of the participatory planning exercise coincided with the winding down of the SIDA-supported ARPT program in Luapula. Consequently, the Finnish 'facilitators' assigned to the planning exercise were able to draw on an unusually 
qualified group of Zambian scientists, most of who had been working for ten years on developing 'farmer-research dialogue' concerning community food security needs and their solution. The veterans of the ARPT program brought to the planning exercise, and the resulting project document, clear ideas grounded in substantial experience about how a dialogical development intervention should be designed.

In line with the ARPT approach described by Drinkwater, the understanding of development underlying this exercise was grounded in a normativity of knowledge that is empirical, pragmatic and syncretic, representing the concrete experiences of individuals and communities eking out a livelihood under conditions of uncertainty and constraint. According to this view, ideological oppositions between modernity and tradition, endogenous experience and scientific knowledge have little relevance for the economic strategies of these rural producers. Peasant producers are well known to adopt innovations, adapt techniques, improvise and experiment with new ideas. 'Local knowledge' is 'traditional' only in the sense that it forms a repository for accumulated wisdom. Within the practical limits imposed by the vicissitudes of their natural and economic environments, the local performances of the agricultural cycle in rural Zambia incorporate ideas, materials and techniques from ail available sources ${ }^{30}$.

The new 'Luapula Livelihood and Food Security Program' has been in operation for a little more than a year (although the dialogic processes on which it is based were commenced 2-3 years ago). It is thus much too early to carry out a proper evaluation of its substantive achievements. Yet already at this stage it is possible to summarize the major ways in which this project differs from earlier interventions in this part of Zambia. I would say that there are five main differences :

I. A policy shift in conceptualizing 'rural development': from 'growth and modernization' to 'food security'

- stress on poverty alleviation

- foregrounding of provisioners (women)

II. Decentralization (to sub-provincial level) of certain administrative powers

- definition of substantive goals

- resource allocation (but not financial controls)

- formulation of work plans

V. A 'process' as against a 'product' focus

- begins with problem identification by actors

- valorization of local views and knowledge in defining solutions

It thus seems that principals which have attained the status of high rhetoric in much of the rural development literature were actually being pursued (and in many cases achieved quite substantially) in Luapula. Experiences from other extension-based projects in Africa suggest that this is not an isolated case ${ }^{31}$. With respect to the self-conception and behavior of the extension staff, the differences are striking. Instead of racing around from farmer to farmer, commanding and pontificating on the Lima Way to maize production, the local extension personnel, from Provincial Agricultural 
Officer to camp officer, are taking time to sit and listen. They can be found patiently debating the interpretation of trials carried out by Farmer Research Groups in remote villages, linking on-station husbandry with the results of village innovators' own breeding experiments.

Extension staff are naturally pleased with the perks that donor-assistance implies: many have received bicycles or Hondas and their claims for allowances have been met with more consistency. But the extensionists I spoke with also claimed to benefit from the new approach. Their work now revolves around groups instead of individual farmers, and this saves time and travel. They also enjoy their role as mediators between research and the end-user, especially when after 14 years of adaptive agronomics the Dept. of Agriculture has begun to release improved varieties of the most important local crops (cassava, millet, groundnuts, beans as well as sorghum-a 'new' but promising innovation in this area) which have proved their success in local conditions.

There are naturally problems and constraints. It is far from clear whether the central ministry or the donor organization are fully committed in the longer term to the processes they have initiated. It is especially difficult to predict the extent to which such changes will become institutionalized with diminishing donor contributions (both project-specific, and in the aggregate). But compared to the situation in the early eighties, the change has been both remarkable and undeniably positive. Where earlier generation of 'expert-stance, supply-driven, top-down, modernization-oriented' approaches systematically marginalized local farmers, the new generation of rural development projects address their needs and bolster their dignity and self-respect.

On applied anthropology in a liberalized economy

Many would assume that the 'anthropology of social change and development' is an applied art not interested in merely understanding, but also in influencing the course of 'development', especially in relationship to interventions or 'projects'. I agree, and find myself attracted as an anthropologist to 'development,' because of the potential (albeit seldom realized) it offers to promote the use of aid resources to improve the livelihood opportunities of those who have so graciously hosted my trespasses in rural Zambia, and others like them. But how to do this? There is a strong tradition in applied anthropologist, dating from colonial times, of the anthropologist as the mouthpiece, the advocate. Applied, or 'development' anthropology generally implied explaining to the Government or to the Donor just what intensive fieldwork experience has taught one about what the people really have or don't have, want or don't want, think or don't think. As it has become increasingly clear that what 'the people' want is a voice of their own, without outside intermediaries, the role of the advocate anthropologist has lost much of its currency.

The void created by the demise of this role has gradually been invaded by another set of practices. Increasingly, in the context of development, applied social science implies training, guiding, catalyzing: 'facilitating a participatory process'. The role of the 'facilitator' puts one where the action is, so to speak, but carries with it many of the contradictions of the advocate. What if the intervention itself is not really worth participating in? What if the process unfolds in such a way that it foments collisions of interest, yet is ill-equipped to 'facilitate' their satisfactory resolution?

The actor-oriented approach to the analysis of development interfaces would seem to offer a third perspective, that of analyzing the 'development intervention' as a hermeneutic configuration : as communicative interaction between parties, structured 
by interests, values and power. One of its major strengths is that the actor-oriented approach offers a 'transcendental' perspective. It presumes to see social interaction from a vantage point that can understand all points of view, but is committed, normatively, to none ${ }^{32}$.

In practice, when studying the 'interface' between, for example, extension agents and peasant farmers, the evaluative deck would appear to be stacked against the government and its representatives. Analyses grounded in the 'negotiated development' mode! appear predisposed to assume that the main parties to the negotiation of development are the farmers on the one hand, and a state-donor monolith on the other, whose face-to-face representative at the bargaining table is the local extension officer. Witness the actor-oriented analyses of Hedlund and Gatter cited above, and many other examples spring to mind. Such analyses have tended to stress the authoritarian structure of the interaction which represses local initiative, participation and knowledge. This authoritarianism is seen to derive from the nature of the state and its 'modern' community of values of which the extension officer is merely an appendage.

This perspective reduces the 'interests' of this particular category of development agent (and, by inference, those of the client brokers) to that of the state : either in utilitarian fashion - as actively complicit to clientalist 'rent-seeking' - or as 'value-driven,' with the minor practitioner portrayed as a dumb pawn to the bureaucratic imperatives of the Department of Agriculture. This is generally as far as the analysis goes. The configuration of power and concomitant interests between client and patron is assumed to be irreconcilable unless the client farmer relinquishes volition, and submits to the agenda of the government worker. Negotiation is indeed possible, perhaps inevitable. But such negotiations are somehow over-determined by the nature of power itself.

I suggest that the proliferation of participatory interventions implies both the possibility and the necessity of going beyond this polar framework, and requires that anthropologists give serious consideration to the issue of positioning themselves with respect to the objects of analysis. Engagement with such processes raises questions about the role of the anthropologist which render the classical categories of advocate, facilitator (or detached, 'objective' critic) inadequate.

In practice, the new generation of participatory projects never achieves a significant 'empowering' of the intended end beneficiaries (dairy farmers, bull owners, crop producers, members of women's groups, etc.) vis-à-vis the immutable (global) structures of economic and political marginalization. No kinds of project, 'participatory' or otherwise, can effectively undermine the over-riding structures of domination that are pushing Africa into the margins of the world economy, and rural African farmers into the margins of that precarious margin. Any improvements which accrue to rural actors are in the immediate sphere of everyday life and should be assessed in this context. Most commonly, an emphasis on 'participation,' or 'empowerment' or 'recipient ownership' means giving primary and secondary level civil servants a greater deal of autonomy and influence over how an intervention is designed and carried out.

Pulling dawn the bureaucrats

51 The analytical point which seems to emerge from the Luapula materials is that by engaging in participatory processes of problem identification and technology 
development, local civil servants can be to some, and variable, extent 'pulled down' into the ranks of the beneficiaries. When this occurs, the lines of negotiation no longer fun clearly between 'the state' and civil society, but cut through the institutions of both spheres. No longer is the extension officer committed to the promotion of an 'alien' technology, conceived of and imposed from above. Via the collaborative process, the civil servant' s primary labor is not one of convincing 'lazy' villagers about their best interests, but rather in struggling with them to secure the resources in order to multiply, disseminate and further adapt the new technologies they have developed together ${ }^{33}$.

52 Experiences such as those of the Luapula experiment suggest an emerging situation in which local civil servant mediators are being both pushed and pulled into the ranks of the development brokers. This is reflected in the way that educated professionals tend, more and more, to migrate among different roles : civil servant, donor-funded project manager, NGO facilitator. From one perspective, one might say that the bureaucratically-based professional stratum has begun to penetrate areas of 'civil society' at the local level. Seen another way, this could be a breaking apart, or fission, of the 'managerial elite.'

'Interests' are centrally at issue. The 'ideal' interests (in Weber's usage) of the development broker are not those of the state functionary. Where civil servants are tied to, and through their actions reproduce, the rule-oriented realm of the bureaucracy, the broker's interests are entrepreneurial, managerial - one might say, result-oriented. For the aid manager designing an intervention this observation raises the issue is of how to engender a project environment which cultivates such managerial interests. Christoplos and Nitsch address this issue in the study cited earlier. Their advice to the Swedish aid agency, Sida, is that 'good governance can only emerge by building upon, rather than suppressing, the motivations of field staff ${ }^{34}$.

I agree, but would go further. Not only should interventions foment result-oriented interests among the professional class, it should do so in way that these interests become identified with results that are in the greater common good. Going beyond 'negotiation', then, cannot mean a naïveté about power. For all the liberalization of the market and the concomitant de-monopolization of the state's role in the delivery of basic services, structures continue to be hierarchical and based on domination. Yet, as David Hecht and Maliqalim Simone remind us, the face-to-face exercise of domination begets vulnerability ${ }^{35}$.

Liberalization is clearly contributing to the vulnerability of local-level civil servants, and changing their relations with various categories of development broker. Indeed, as the line between 'facilitator' and 'participant' begins to shift, it is no longer clear who is negotiating what, and with whom. It is getting to the point that local bureaucracies cannot survive without donor projects, and public sector officials are increasingly having to compete with the private sector and NGOs for donor attentions. The increased power which a District Agricultural officer, or a camp-level extension worker may gain through the decentralization of a the agricultural administration implies a sacrifice of bureaucratic autonomy. Participatory methodologies can also create new channels of accountability - not only to upstream superiors and donor evaluators, but to the clientele whose participation they must facilitate. Projects like the Luapula LFSP exhibit signs of this occurring, albeit embryonically. The challenge to development 
anthropology is of understanding what factors constrain or enable collaboration and accountability, and how it might be institutionalized.

Where do anthropologists come in ? I propose three basic points :

I. Development anthropologists need a clearer focus on processes, not products. This need not be an either/or choice, but in some situations the main point may not be the unpacking of a technology, but the nature of trust, or domination, upon which 'participation' is based.

II. This suggests three areas for more analytic work :

- the need for a re-theoretization of the social relationships of development interventions;

- the need to rethink the position of the research vis-à-vis participatory processes ; and closely related to both of the above,

- the need to reconsider issues of power and domination in development interventions.

III. Finally, there should be more collaborative engagement, working with local researchers (who more and more call themselves 'consultants') Outsiders can often bring insights into the institutional (or organizational) dynamics of interventions that local actors may not see so clearly. But most important in the present situation is to enlarge the space for local intellectuals to engage in these processes beyond the established roles of 'advocate' or 'facilitator'.

\section{NOTES}

1.Norman Long (ed.), Encounters at the interface. A perspective on social discontinuities in rural development (Wageningse Sociologische Studies 27 (1989) was a watershed collection ; see also N Long \& A Long; Battlefields of Knowledge (Routledge 1992). Jean-Pierre Olivier de Sardan's discussion of brokerage is also pertinent in this connection; see his Anthropologie et développement. Essai en socio-anthropologie du changement social (Paris : APAD-Karthala 1995), esp. chapter 9 : 'Médiations et courtages.' In the Zambian context, see Kate Crehan and Achim von Oppen, 'Understandings of "development" : an arena of struggle. The making of a development project in North-Western Province' in their (eds.), Planners and history. Negotiating 'Development in rural Zambia (Lusaka : Multimedia 1994). Also Han Seur, Sowing the good seed The interweaving of agricultural change, gender relations and religion in Serenje District, Zambia (Ph.D. thesis, Wageningen 1992) ; and less explicitly, Philip Gatter, Indigenous and institutional thought in the practice of rural development : a study of an Ushi chiefdom in Luapula, Zambia (Ph.D. thesis, SOAS 1990).

2.David Booth, Rethinking social development. Theory, research \& practice (Longman 1994), p. 13.

3.These project analyses were part of a study on 'Ownership in the Finnish Aid Programme' (Helsinki : Finnida Evaluation Report 1996 :3). The arguments put forward here are solely my own, and should not be attributed to other members of the study team, nor to Finnida. 
4.I Christoplos \& U. Nitsch, Pluralism and the extension agent. Changing concepts and approaches in rural extension (Sida : Department for Natural Resources and the Environment 1996), p. 52 (emphasis in original). Christoplos and Nitsch are based the Swedish University of Agricultural Sciences.

5.See J. Gould, Luapula - dependence or development? (Lusaka : Zambian Geographical Association 1989).

6.E.g. Peter Stromgaard, 'A subsistence society under pressure : the Bemba of Northern Zambia' Africa vol. 55, n 1 (1985), pp. 39-58.

7.H. Moore \& M. Vaughan, Cutting down trees. Gender, nutrition and agricultural change in the Northern Province of Zambia, 1890-1990 (Portsmouth : Heinemann \& London : James Currey 1994).

8.See Gould 1989.

9.Moore and Vaughan, Chapter 2.

10.Kusum Datta, 'The political economy of rural development : the case of the Luapula-Bangweulu area in Zambia 1947-53', History Staff Seminar 1982/83, University of Zambia (mimeo) p. 14 ; (also published in International Journal of African Historical Studies, vol. 21, nº 2 (1988), pp. 249-72). Citations herein are drawn from the mimeo version. Paradoxically, colonial agriculturists carried out extensive research in traditional agricultural systems. The exemplar of this work is William Allan's classical study of citemene, The African Husbandman, which was not published until 1965. As Moore \& Vaughan point out (op.cit.), research that revealed the rationality of indigenous systems of cultivation was systematically subordinated by the premise that 'African agriculture' was wasteful and inefficient.

11.Datta., pp. 17-19.

12.See R.E. Baldwin, Economic Development and Export Growth : a study of Northern Rhodesia 1920-1960 (Berkeley : University of California Press), p. 201.

13.'Northeastern region' here refers to the administrative unit known at the time as the Northern Province, which from 1953-58 comprised both the Northern and Luapula Provinces of present-day Zambia ; see J. C. Stone, A Guide to the Administrative Boundaries of Northern Rhodesia (University of Aberdeen 1979) ; Gould 1989, p. 17.

14.Northern Rhodesia. Department of Agriculture. Annual Report for the Year 1954. Lusaka Government Printer 1955.

15.Northern Rhodesia. Department of Agriculture. Annual Report for the Year 1956. Lusaka Government Printer 1957, pp. 8-9.

16. Northern Rhodesia. Department of Agriculture. Annual Report for the Year 1960. Lusaka Government Printer 1961, p. 11.

17.Registrar of Co-operative Societies. Annual Report for the Year 1947. Appendix "A" : Résumé of agreed policy on the development of African producer co-operative societies (Lusaka : Government Printer 1948), p. 11 (my emphasis).

18.E.g., Samuel N. Chipungu, The state. technology and peasant differentiation in Zambia. A case study of the Southern Province 1930- 1986 (Lusaka : Historical Association of Zambia 1988)

19.'Lima' derives from ukulima (to cultivate). The 'Lima Programme' as used here refers to a specific set of chemo-genetic technologies (revolving, originally, around the SR-52 breed of hybrid maize), the extension/training curricula for disseminating these techniques, as well as to the policy upon which this dissemination was based, which encompassed a co-ordinated array of training, credit and marketing facilities. A 'lima farmer,' is someone participating in the program. There is a broad literature on the 
lima concept and its career in Zambian agricultural policy ; see for example A.P.Wood, et al, The Dynamics of agricultural policy and reform in Zambia (Iowa State University Press, 1990), Crehan \& v. Oppen, Gatter.

20.Hans Hedlund, 'Development in Action : the experience of the Zambian extension worker', Ethnos 49, 3/4 (1984), pp. 226-50.

21.Ibid., pp. 244, 250.

22.Gatter, op. cit., Chapters $3 \& 4$.

23.P. Joy, 'The crisis of fanning systems in Luapula Province, Zambia' in A. Hurskainen and M. Salih (eds.), Social science and conflict analysis (Uppsala : Nordiska afrikainstitutet 1993), p. 132.

24.S.A. Kean, 'Developing a partnership between farmers and scientists : the example of Zambia's Adaptive Research Planning Team,' Experimental Agriculture, vol. 24, part 3 (1988), pp. 12-3 ; a1so his Ph.D. thesis, 'The institutional politics of agricultural research policy in Zambia : a model of contingent innovation' (University of East Anglia 1993). 25.M. Drinkwater, 'Knowledge, consciousness and prejudice : adaptive agricultural research in Zambia'. In Ian Scoones \& John Thompson (eds.), Beyond farmer first : rural people's knowledge, agricultural research and extension practice (London : IT Publications 1994).

26.Ibid., p. 38

27.Ibid., p. 40.

28.E.g., Drinkwater's discussion of 'Serena' sorghum ; ibid., p. 37.

29.For example, the extension philosophy incorporated in the World Bank funded Agricultural Sector Investment Program is a direct heir to ARPT methodologies. 30.See Paul Richards, 'Cultivation : knowledge or performance ?' in M. Hobart (ed.), An anthropological critique of development. London : Routledge (1993), pp. 61-78.

31.Similar experiences are reported from the Finnida supported RIPS program in south-eastern Tanzania ; see Lars Johansson, 'Reforming donor driven projects and state bureaucracies through PRA,' Forests, Trees and People Newsletter $N^{\circ} 26 / 27$ (April 1995), pp. 59-63. For a similar example, see Jürgen Hagmann et al., 'lmproving the output of agricultural extension and research through participatory innovation development \& extension : experiences from Zimbabwe,' European Journal of Agricultural Education and Extension, vol. 2, $\mathrm{n}^{\circ} 3$ (March 1996).

32.In this respect, I find the work of the Mexican anthropologist Magdalena Villarreal particularly interesting. See especially her thesis : Wielding and Yielding : Power, subordination and gender identity in the context of a Mexican development project (Wageningen 1994).

33.I refer again to the case of Serena sorghum in Drinkwater's piece (note 28).

34.I Christoplos \& U. Nitsch, op.cit., p. 53 (emphasis in original).

35.D. Hecht \& M. Simone, Invisible Governance. The art of African micropolitics. Brooklyn : Autonomedia (1994), p. 14 


\section{AUTEUR}

JEREMY GOULD

University of Helsinki, Institute of Development Studies, Box 47, 00014 Helsinki. Tél.

+358.0.708.4760. Fax. +358.0.708.4778 - jeremy.gould@helsinki 